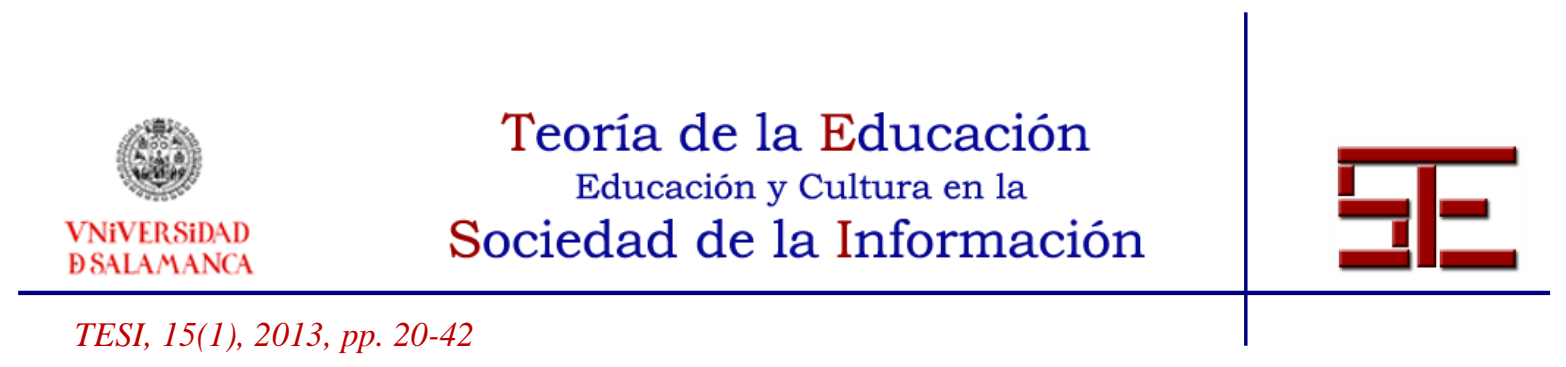

\title{
UNDERSTANDING MOBILE LEARNING: DEVICES, PEDAGOGICAL IMPLICATIONS AND RESEARCH LINES
}

\begin{abstract}
The development of new technologies and the interest in their applications in the teaching-learning process have caused the emergence of new didactical methodologies, which intend to get the most out of the devices. Within these methodologies, mobile learning has gained a significant importance. Our aim with this article is to describe the main characteristics of this methodology, focusing on the pedagogical implications it entails and the current research situation in this field, especially in Europe and Spain.

The article is divided into four sections. In the first place, we will define the concept of mobile learning and its relation to the education field. Secondly, we will describe the didactical possibilities of mobile devices, focusing on the most popular ones: smartphones and tablets, which have entailed an important advance in this field. Thirdly, we will go into detail about the pedagogical criteria for the development of mLearning activities in the different educational paradigms and contexts as well as the teacher training strategies. Lastly, we will present the main lines of research and current trends and we will describe the situation in the previously mentioned territories.
\end{abstract}

Key words: mLearning; eLearning; pedagogical uses; didactic principles; mobility; ICT,; educational research.

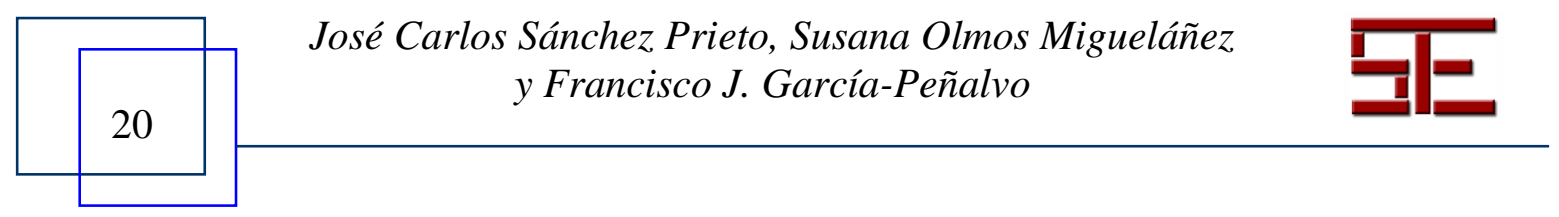




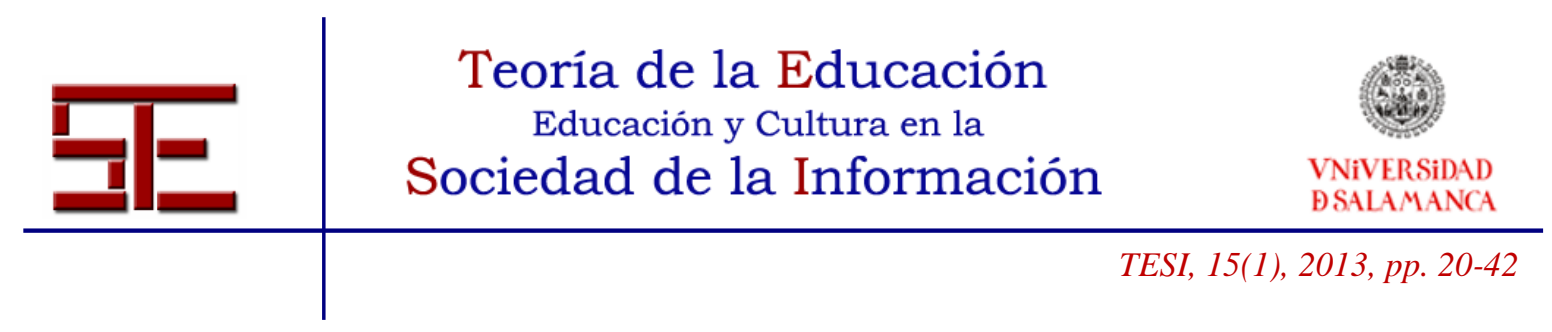

\section{COMPRENDIENDO EL APRENDIZAJE MÓVIL: DISPOSITIVOS, IMPLICACIONES PEDAGÓGICAS Y LÍNEAS DE INVESTIGACIÓN}

Resumen: El desarrollo de las nuevas tecnologías y el interés en la aplicación de las mismas al proceso de enseñanza aprendizaje han provocado el nacimiento de nuevas metodologías didácticas que pretenden sacar el máximo partido a los dispositivos. Una de las que más fuerza ha cobrado en los últimos años es el mobile learning. Nuestra intención con este artículo es describir las características principales de esta metodología, centrándonos especialmente en las implicaciones pedagógicas que trae consigo y la situación actual de la investigación en este campo, especialmente en España y en Europa.

El artículo está dividido en cuatro secciones. En primer lugar, definiremos el concepto de mobile learning y su relación con los ámbitos de enseñanza. En segundo lugar, pasaremos a describir las posibilidades didácticas de los terminales móviles, centrándonos especialmente en los más populares en la actualidad, smartphones y tabletas, que han supuesto un importante avance en este campo. En tercer lugar, profundizaremos en los criterios pedagógicos para el desarrollo de actividades mLearning en los distintos paradigmas y contextos educativos, así como las estrategias de formación del profesorado. Por último, presentaremos las principales líneas de investigación y tendencias actuales y describiremos la situación en los territorios mencionados anteriormente.

Palabras clave: mLearning; eLearning; usos pedagógicos; principios didácticos; movilidad; TIC; tendencias; investigación educativa.

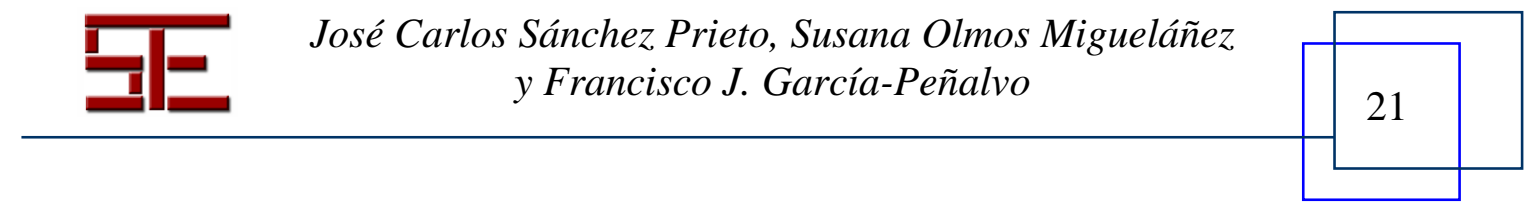




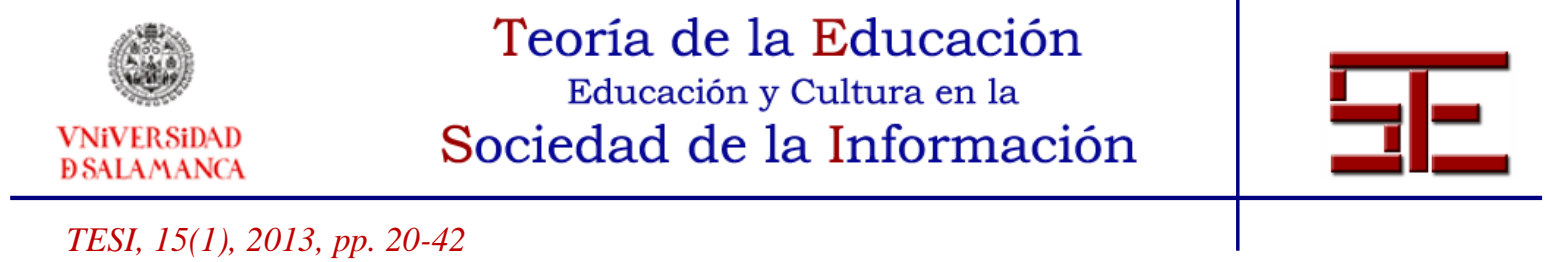

\section{UNDERSTANDING MOBILE LEARNING: DEVICES, PEDAGOGICAL IMPLICATIONS AND RESEARCH LINES ${ }^{1}$}

Fecha de recepción: 22/010/2013; fecha de aceptación: 17/12/2013; fecha de publicación: 28/02/2014

José Carlos Sánchez Prieto

(josecarlos.sp@usal.es)

Grupo de Investigación GRIAL, Instituto Universitario de Investigación en Ciencias de la Educación, Universidad de Salamanca

Susana Olmos Migueláñez

(solmos@usal.es)

Grupo de Investigación GRIAL, Instituto Universitario de Investigación en Ciencias de la Educación, Universidad de Salamanca

Francisco J. García-Peñalvo

(fgarcia@usal.es)

Grupo de Investigación GRIAL, Instituto Universitario de Investigación en Ciencias de la Educación, Universidad de Salamanca

\section{1.- INTRODUCTION}

The incorporation of information and communication technologies (hereinafter referred to as ICT) entails the need to make constant methodological changes to get the most out of the possibilities they offer (Fernández Gómez et al., 2009).

Through the last decade different scientific disciplines, including pedagogy, have explored the educational possibilities of technologies such as the Internet or videogames.

We have witnessed how new ICT-related terms have emerged and gained strength, such as eLearning, a term that, although can make reference to any teaching/learning process that makes use of electronic means, it is mainly used to refer to the learning process developed through the Internet, as this has become the basic tool for developing distance education processes (García-Peñalvo, 2005).

Due to its relationship with technological innovation, eLearning has been constantly changing to adapt to the new possibilities and demands, evolving into eLearning 2.0

\footnotetext{
${ }^{1}$ We would like to thank the Regional Council of Education of Junta de Castilla y León (Spain) through the projects GR47 and MPLE (ref. SA294A12-2). Finally, the authors would like to thank the partners of GRIAL, http://grial.usal.es, for the received support.
}

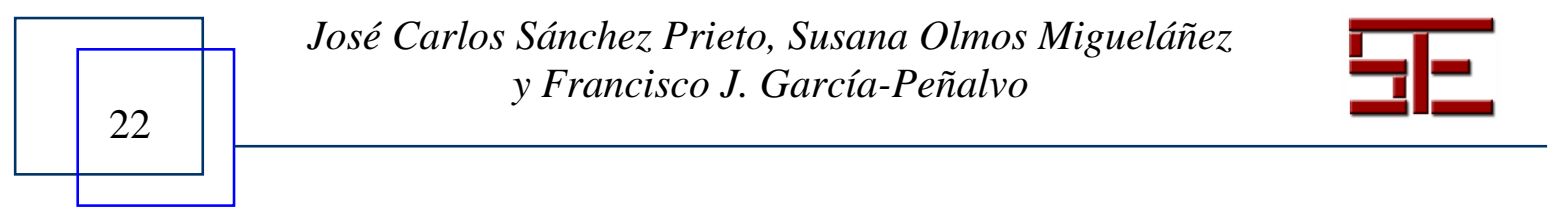




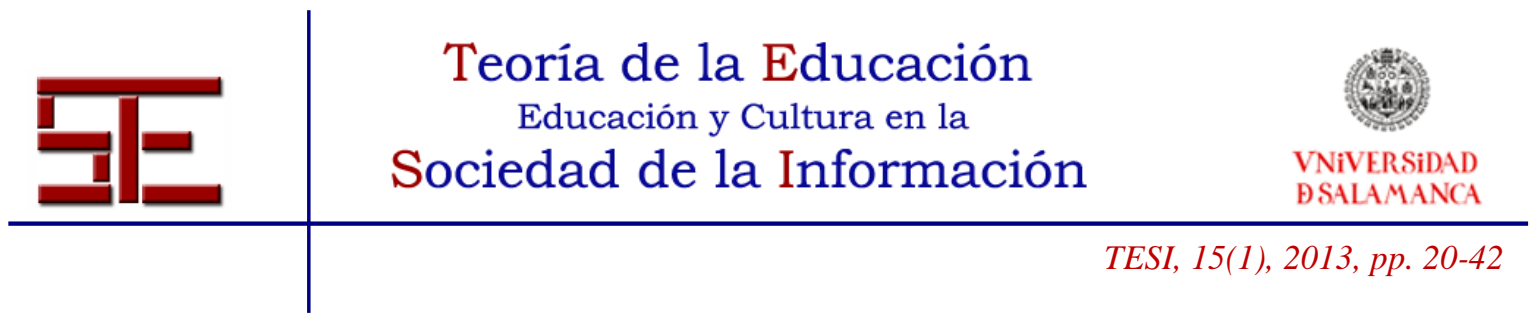

seeking to integrate the changes introduced by web 2.0, and trying to provide a more flexible, personal and social teaching-learning process, which is leading to initiatives such as University 2.0 (Berlanga, García Peñalvo, \& Sloep, 2010).

The notion of elearning has also been branching out, giving rise to new methodologies that try to get the most of certain technologies. It is in this context that concepts like gLearning, cLearning or mLearning emerge.

MLearning constitutes one of the most popular fields in the past few years, arises due to the success of the mobile terminals in the various social social strata, with an expected worldwide penetration of 96\% in 2013 (Fundación Telefónica, 2013), and intends to explore the educational possibilities of these resources.

The present article offers a description of the current situation of mobile learning as an educational methodology and field of research, suggesting pedagogical principles for the development of mLearning activities.

The article is organized in five sections. The first one will be dedicated to the definition of mobile learning and its relationships with other methodologies and the educational field. We will continue with an analysis of the different devices that can be used in mobile learning activities, paying special attention to the new possibilities and practical applications of smartphones and tablets. Thirdly we will explore the didactic and pedagogical implications of this modality, and the teacher training strategies allowed by this methodology. The fourth section will present a description of the main lines of research and current trends, focusing on Europe and Spain. Finally, in the fifth section we will offer a series of conclusions derived from this review.

\section{2.- MLEARNING: MEANING AND EDUCATIONAL FIELDS}

Mobile learning can be understood in a variety of ways, depending on the element that we focus on (Taylor, 2006):

- Learning through mobile terminals.

- Learning with students that are on the move.

- Learning through mobile content.

The existing definitions of mobile learning are different, depending on which of the previous contexts the author emphasizes. In the literature, we can find authors who limit themselves to the technological (Quinn, 2000) and also broader definitions that include the role of the student (O'Malley et al., 2003) or the three aforementioned elements, which is the case of Petrova and Li (2009), who define mobile learning as "an ubiquitous learning activity occurring through person-to-person communication using a

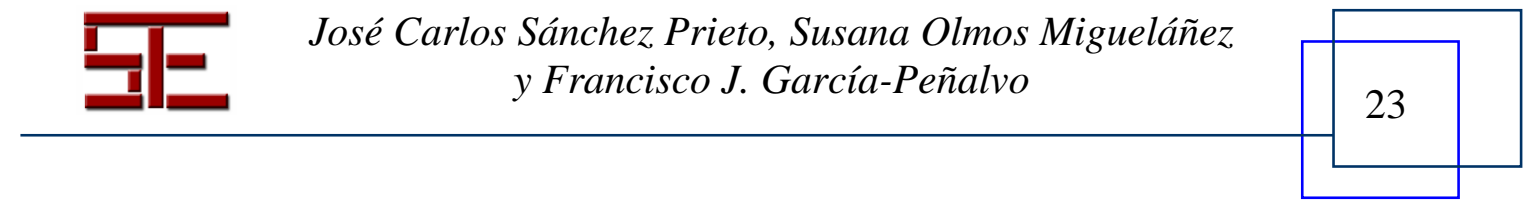




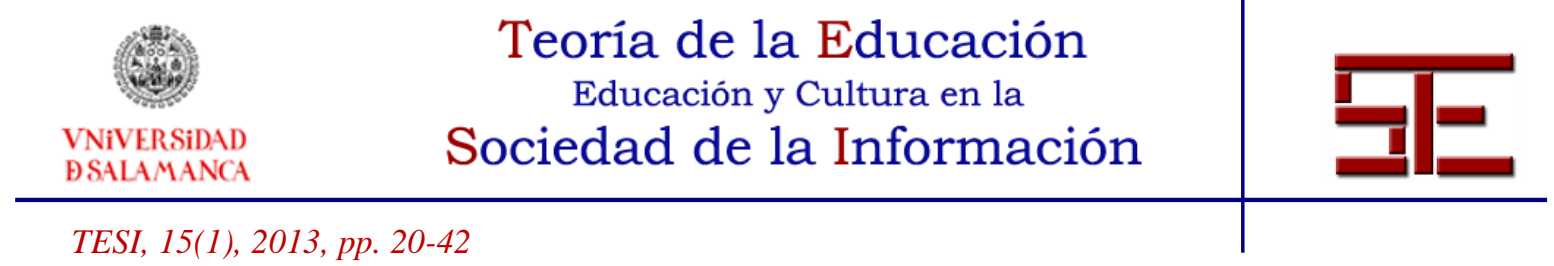

mobile device which is supported by an appropriate mobile technology, user interface and a pedagogical approach". These authors do not only mention the technological component, but they also focus on the mobility, and they describe the three fundamental components of mobile learning: hardware, interface and pedagogical design.

Regarding the relationship between mLearning and the educational fields, mobile learning has traditionally developed within the non-formal education field, which constitutes an important obstacle towards its integration in the formal field of education (Traxler, 2009), where it is considered by many authors as a complement of presencebased learning (Laouris \& Eteokleous, 2005) or as a bridge between formal and nonformal contexts (Merchant, 2012). Despite this, a growing number of researches request a greater presence of mLearning in formal education contexts ( Cochrane, 2011; Terras \& Ramsay, 2012).

Mobile terminals offer many possibilities to students regarding communication and autonomous work, being an important resource when it comes to develop Personal Learning Environments (Humanante Ramos \& García Peñalvo, 2013) or in collaborative work contexts. Thus, the line between formal and informal learning blurs, and this demands the rethinking of the traditional teaching strategies (Sharples, Amedillo Sanchez, Milrad, \& Vavoula, 2009).

The development of mLearning and the widening range of opportunities to develop educational processes anytime anywhere will eventually lead to a new learning methodology: the ubiquitous learning or uLearning, learning every time everywhere. In this methodology the student would find himself in a situation of permanent learning, surrounded of learning elements, to the point that the learning could even take place unconsciously (Jones \& Jo, 2004).

This way, mLearning would be situated halfway between eLearning and uLearning, and it can be defined as "an evolution of eLearning which allows students to take advantage of the possibilities allowed by mobile technologies to support their learning process and which constitutes the first step towards the creation of ubiquitous learning" (Conde, Muñoz, \& García, 2008).

\section{3.- CHOOSING THE PROPER TECHNOLOGY}

When it comes to determine which terminals are susceptible of being used to develop mobile learning activities, considering as mobile device any object with a processor with memory that has data input and output (Ramírez Montoya, 2009), there is a great variety of technological resources at the teacher's disposal, which goes from Mp4 players to ebooks, including PDAs (Corbeil \& Valdés-Corbeil, 2007).

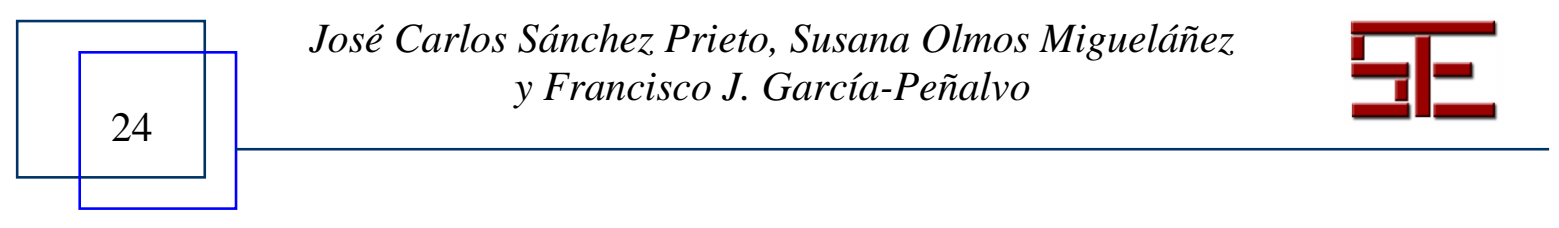




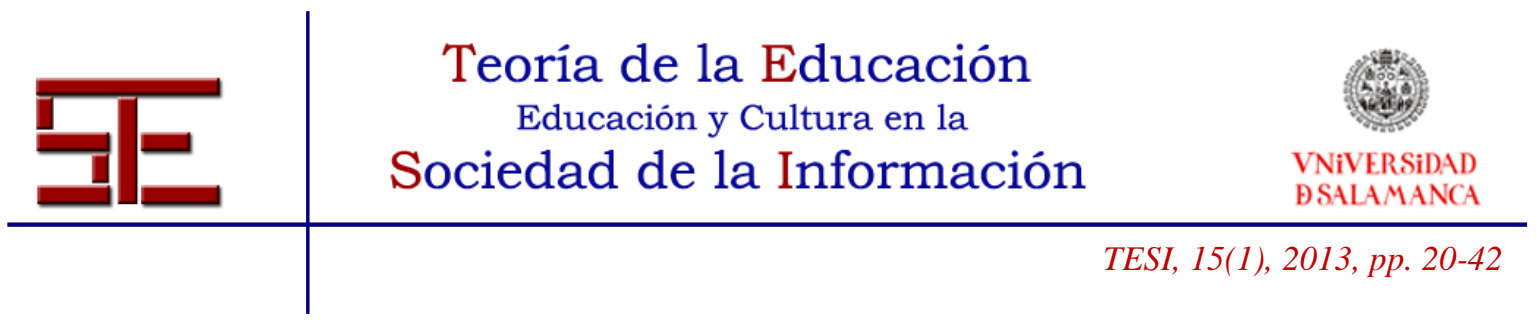

Although the aforementioned devices frequently appear in the bibliography (Korucu \& Alkan, 2011; Peters, 2007), the devices that take up most of the research are smartphones and tablets. Below, we present their features and most important didactical uses.

\section{1.- Smartphones}

Smartphones are small size devices that combine the uses of the conventional mobile phones with those of a pocket pc (Korucu \& Alkan, 2011). They offer internet connectivity and a wide range of functionalities that go from the elaboration of documents and multimedia to the realization of web 2.0 activities.

The popularity of this resource has strongly grown in the last years, displacing the mobile phones (Shin, Shin, Choo, \& Beom, 2011). Its main advantages are reduced size, autonomy, the provision of network connection anytime anywhere, and processor capacity.

Smartphones can be used in a broad set of mobile learning experiences, from game based learning activities (Camargo, Bary, Boly, Rees, \& Smith, 2011) to the distribution of eLearning content (Gopalan, Karavanis, Payne, \& Sloman, 2011).

We can find in the literature significant experiences of the use of smartphones in the field of formal education at all educational levels, from their use as a tool to prepare eportfolios with Pre-primary students' works (Parnell \& Bartlett, 2012) to the creation of mobilized units specifically designed for education through smartphones, which integrate activities inside and outside the school (Zhang et al., 2010).

There also are studies with Secondary Education students, such as the one conducted by Mandula, Meda, Muralidharam and Parupalli (2013), who explored the possibilities of sending lesson videos to the student's terminals, or the one carried out by Kamaruzaman y Zainol (2012) about the possibilities of the M-Language application for smartphones.

In Higher Education there is a growing number of universities that integrate smartphones in everyday activities, whether they are used as a communication tool, a content delivering tool or a basis for collaborative learning activities (Jarvela, Naykki, Laru, \& Luokkanen, 2007; Lum, 2012).

\section{2.- Tablets}

Since the release of the first iPad in 2010, tablets have quickly spread in the mobile devices market. This resource composed of a tactile screen, generally between 7 and 10 inches, offers the same functionalities of a computer and it's handheld without the need of external peripherals.

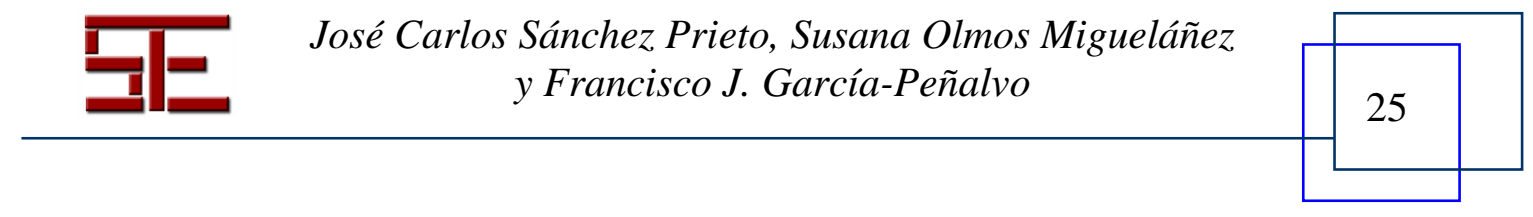




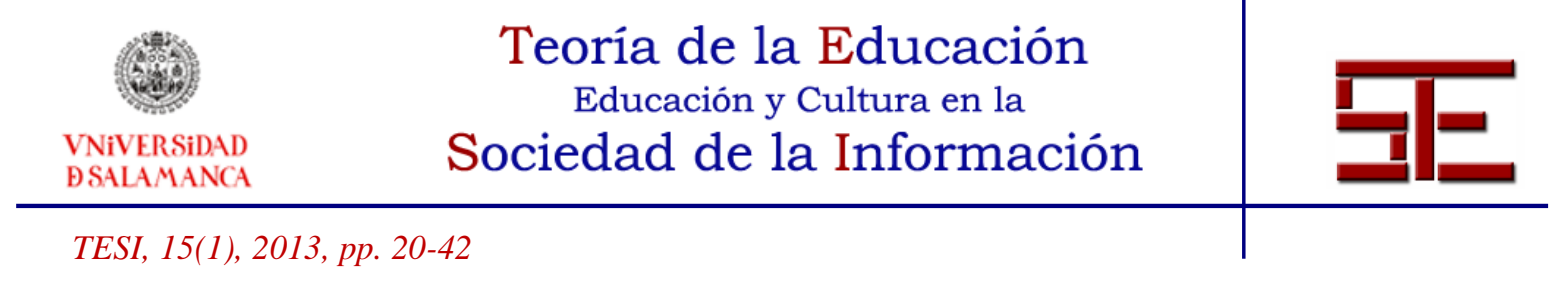

This device is especially useful in the development of mobile learning activities, helping to overcome the difficulties related to the small screen size and power of the rest of technological devices (Álvarez Rosado, Bravo Martín, García Peñalvo, \& Álvarez Rosado, 2013).

This technology allows amplifying the inherent advantages of mobile learning, facilitating the search and consultation of information, the interaction, and the adaptation to different learning styles (Rossing, Miller, Cecil, \& Stamper, 2012).

Although students show a very positive attitude towards these devices (Dündar \& Akçayır, 2014), it is not the same when it comes to teachers, where the opinions are divided (Ifenthaler \& Schweinbenz, 2013).

Also there are still gaps in the development of Tablet-specific educational software. After carrying out a study on the educational potential of the existing applications for iPad, Murray and Olcese (2011), from the University of Pennsylvania, concluded that, although there was no doubt about the potential of these instruments, the software developed until this point didn't take advantage of the new capacities of the device. Since then there has been important advances in this matter, specially noting the launching of Apple's iTunes U, a tool for the elaboration and distribution of contents specifically designed for tablets (Germany, 2011).

The popularity of this technology has made a growing number of schools and universities interested in implementing them (Pegrum, Oakley, \& Faulkner, 2013) with experiences like the ones conducted by Beschorner and Hutchison at pre-primary (2013) and primary (2012) levels who explored the possibilities of iPads in literacy instruction through progressively complex applications that helped children develop their oral and writing skills.

Other possible applications for the Tablets within formal education include, among others, their use as a sole working tool, thus creating zero-paper environments (Hesser $\&$ Schwartz, 2013), as a support for teaching mathematics through game-based learning activities (Carr, 2012) or to execute interactive books (Huang, Liang, Su, \& Chen, 2012a).

\section{4.- PEDAGOGICAL CRITERIA IN THE IMPLEMENTATION OF MLEARNING AND FORMATIVE NEEDS}

In addition to constituting a new technology, mobile learning implies a new methodology that determines plenty of things, from the design of new didactic resources adjusted to the terminals and mobility, to the pedagogical principles that underline them.

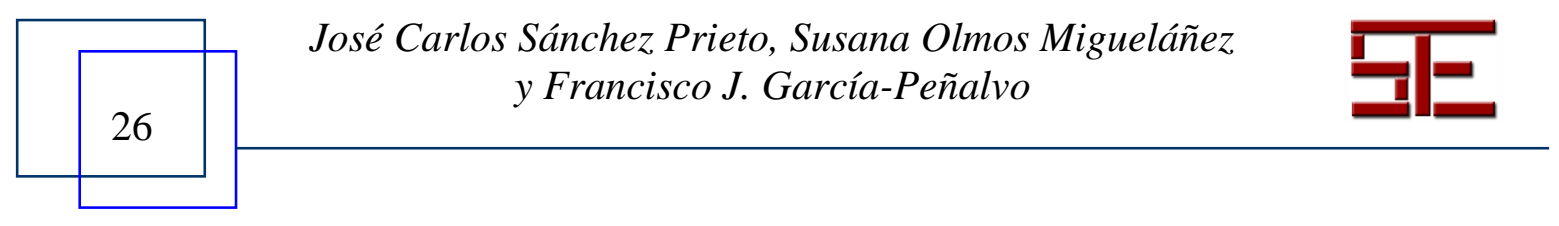




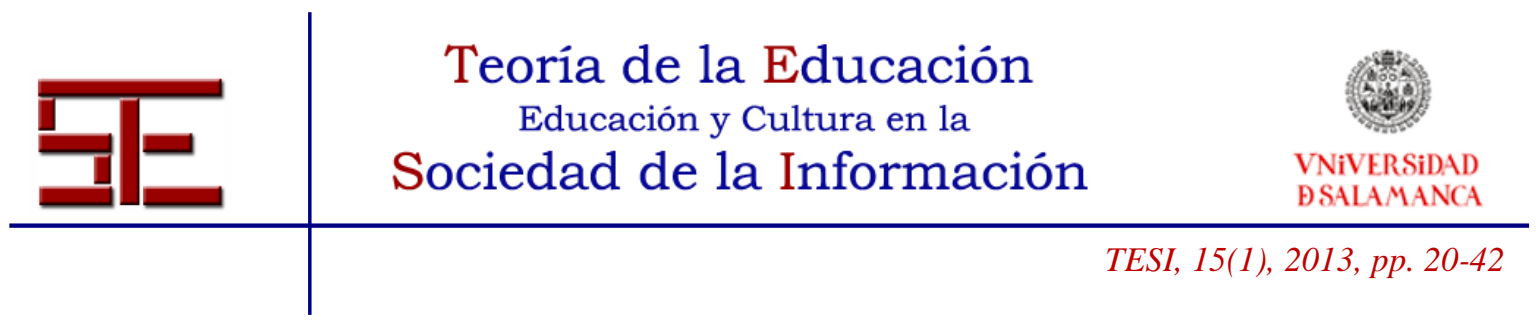

To correctly develop a mobile learning experience, it's necessary to adapt the presentation of contents and the activities to the characteristics of this methodology. This is only possible if we are conscious of the potential and limitations of mobile learning.

As we mentioned before, one of the most important features that mobile technologies offer is the mobility, the capability to break the time and space barriers, allowing the students to learn anytime anywhere by taking the learning tool with them (Marcos, Támez, \& Lozano, 2009), but there are other important advantages such as the immediate application and publication of contents, which is enhanced if we combine mobile technologies and web 2.0 tools (Petit \& Kukulska-Hulme, 2011).

Furthermore, the individual nature of the devices contributes to the customization of the contents and their adaptation to the needs of the individuals and their environment (Traxler, 2009), which, coupled with the multimedia capacity, constitutes an important motivational factor (Rodrigo, 2011).

Lastly, we would also like to highlight the communicational features, especially useful in the development of collaborative activities, which help establish group work processes and help develop creativity and communicational skills among students (Organista \& Serrano, 2011).

Although mobile learning can provide a wide range of educational solutions, there are some difficulties to overcome when it comes to designing our own activities.

Orr (2010) summarizes these factors, and he points out the most important ones: the technological difficulties originated both by hardware and software that, despite the progress achieved and the appearance of tablets, still limit the array of activities we can conduct. Related to these difficulties, there also are compatibility issues among the different devices, which sometimes demand content readjustments and selection. Besides, the lack of access to the Internet can be a problem due to the activities' dependency on connectivity, which might limit the mobility.

There are other difficulties related with methodological or social factors such as student distraction derived from the multitask context in which the mobile teaching/learning process takes place.

Depending on the context in which the educational process develops, there is the risk of digital exclusion. Mobile learning requires of certain level of technological knowledge that may cause that the advanced users to have certain advantage. Furthermore, the less advanced users may feel intimidated by this technology and stay out or feel isolated (Corbeil \& Valdés-Corbeil, 2007).

These inequalities can be especially significant in socially unequal contexts, where students from upper classes might show better tool-handling skills than their lower class

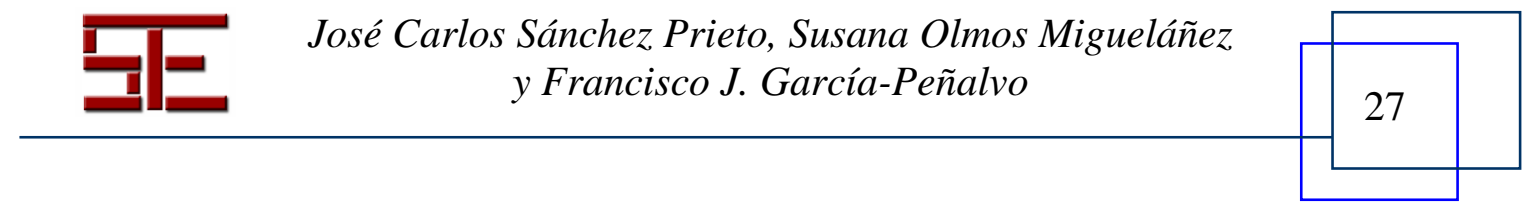




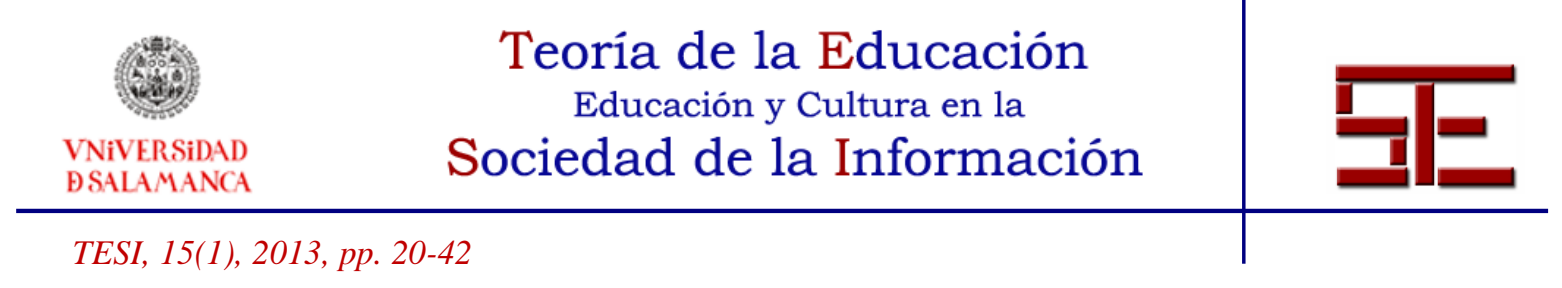

counterparts. However, with the right methodology, the introduction of these devices in educational contexts might help to reduce the digital gap between social classes (Ferrer, Belvís, \& Pàmies, 2011).

Although some of the factors previously mentioned are related to technological questions, most of them have to do with educational aspects and can be solved by implementing improvements in the didactic design of the activities (Cochrane, 2012).

The integration of the mobile devices into the teaching process depends not only on its general contributions, but also on their educational paradigm. Kadirire (2009), exposes how mLearning is related to the conductist and constructivist paradigms:

-Conductist: Within this paradigm there would be activities such as the delivery of content through the use of text messages or stimuli-response based activities in which a reinforcement message is sent by the system after the student sends his answer.

- Constructivist: In this paradigm the students become builders of their own knowledge through the active participation and the collaboration through their mobile devices and the communication support tools that they offer. The best example of this kind of activities is the participative simulations, activities in which a group of students simultaneously participates in a learning simulation.

Although mobile learning activities can take place within any of the two paradigms, we agree with SCOPEO (2011) in considering that a constructivist designs take better advantage of the possibilities of the terminals given that this theory "is conductive to a social interaction for the construction of knowledge, while allowing the student to build his own scaffolds for significant learning".

Focusing on the application of the mobile technologies to the distance education process, we will take the transactional theory of distance education as a referent. This theory considers the distance as a pedagogical factor determined by three factors: the structuring of the program, the interaction between teacher and student, and the autonomy of the learner (Moore, 2007).

According to this theory, we can classify the mobile learning activities in four groups (Park, 2011):

-Social Learning activities with high transactional distance: It involves activities in which there is a high psychological distance between the students and the teacher or institution and which have a highly structured content. They propose a group work methodology in which the interactions happen mainly between the students, and the teacher has a guidance role.

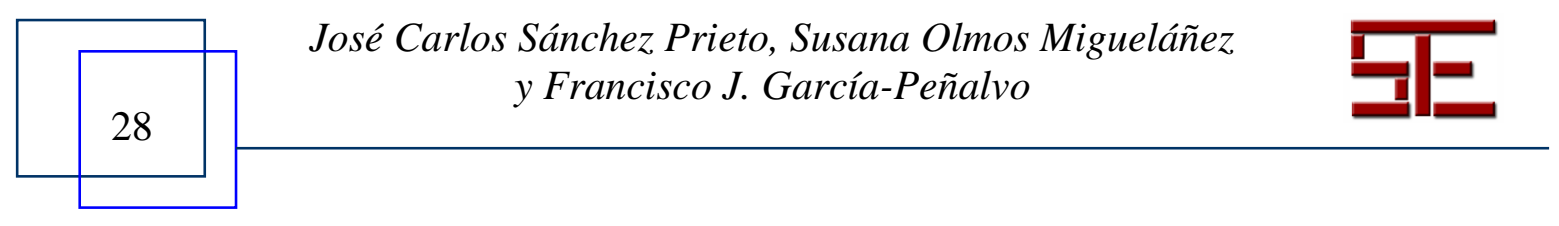




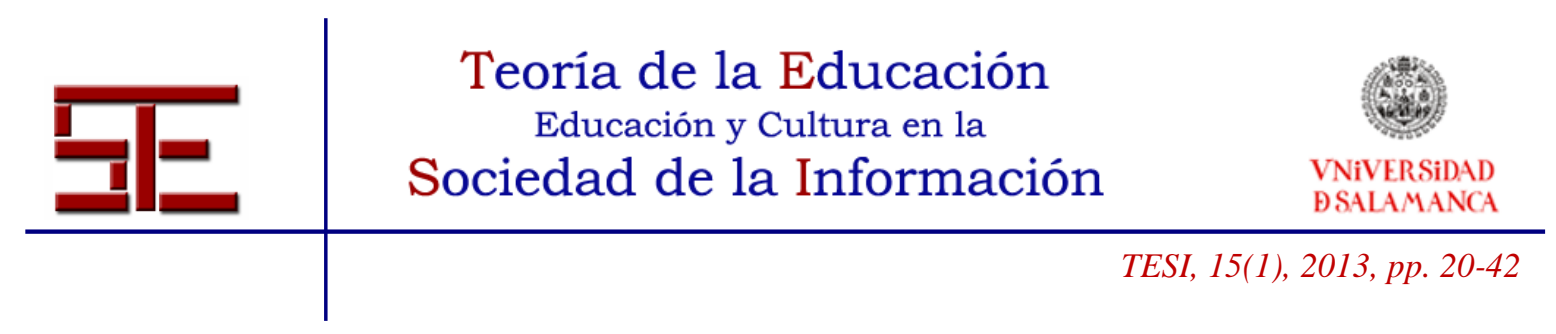

- Individual learning activities and high transactional distance: These are also activities in which there is a high psychological distance between the students and the teacher or institution, and a very structured content. However, in this case, the main interaction takes place between the learner and the content

- Social learning activities and low transactional distance: It involves interventions with a loosely structured content and lower psychological distance between the student and the teacher or institution. The learners work in groups to solve a problem, and interaction processes are established in a natural way.

- Individual learning activities and low transactional distance: These are loosely structured activities with a lower psychological distance between teacher and learner. In these activities, the learners frequently interact with the teacher that monitors their learning process, trying to adjust the contents to their individual needs.

Based on the previously mentioned characteristics, we consider that the mobile learning designs must follow the following principles, elaborated on the contributions of SCOPEO (2011), Elias (2011) and Franklin (2011):

-Short and direct modules: Because of the characteristics of the hardware used to access the information and to take the most advantage of the possibilities anytime, anywhere, that mobile learning offers, it's recommended to design short duration modules, around five minutes long.

- Flexibility and simplicity: The mobile learning activities must take into consideration the difference of skills among the users in order to adjust to their abilities.

- Accessibility and mistake tolerance: It's important that our activities have an intuitive interface that allows the rectification of navigation-related mistakes.

- Multimedia: The integration of multimedia elements in the mobile learning content presentation is a very important factor to considerate due to the short duration of the modules.

- Action oriented: The mobile terminals aren't a reflexive medium; therefore, the approach of the educational process must be practical and immediate.

- Communication and visibility: To use the connectivity and communication capabilities of the mobile technologies to carry out collaborative activities and facilitate the learners to share their contributions.

- Constantly renewed and updated: This aspect makes reference to the content and the methodology used. The evolution of the mobile devices is very fast and it produces new functions that could make the educational process easier.

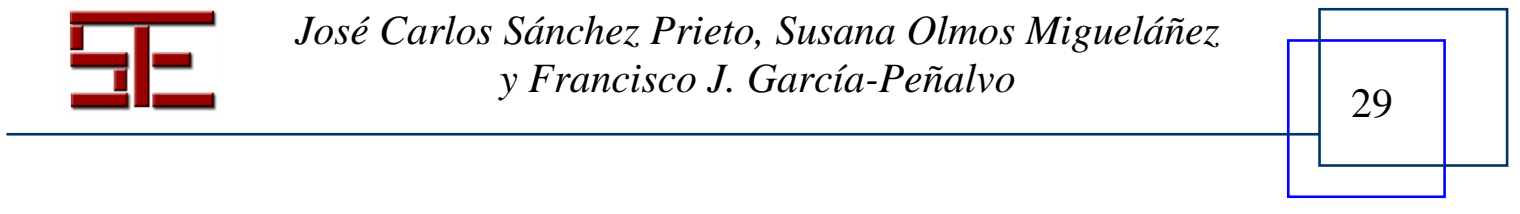




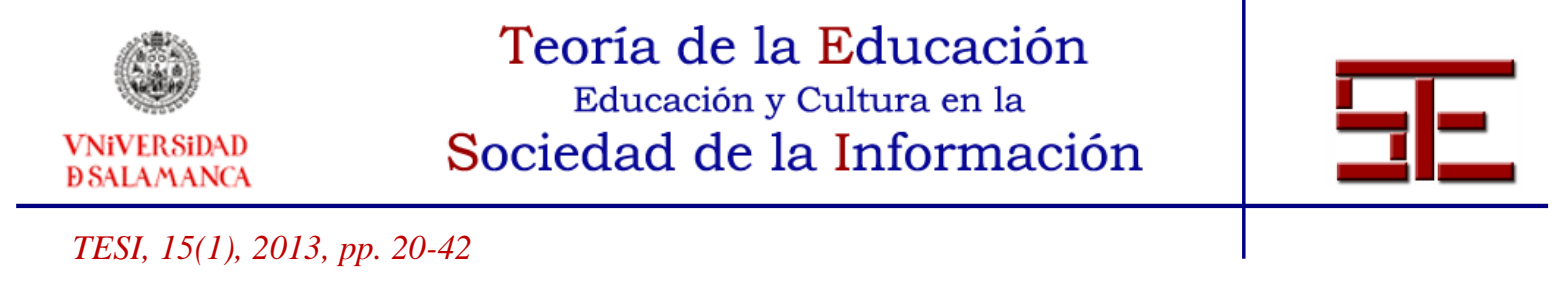

- Adapted to the features of the device: That condition the type of activities that we could develop. It isn't the same designing an activity for mobile phones than an activity for tablets, as there are important differences both on the available software and on the physical conditions of the terminals.

To carry on a successful activity design it's necessary to ensure a teaching body with the proper training.

One way to train teachers is through the use of mobile learning in their own training process, which provides awareness of the possibilities it offers.

The MENTOR ME programme, conducted in the University of Barnet in 2011, is a good example of current research in this field. They carried out a pilot study with 20 education students, who were given a mobile phone with e-mail access along with their teachers. The device delivery was accompanied by a training session for students and teachers about their possible uses in education. The project was a success, both in the improvement of university education and the awareness of the students about the benefits of these devices (Cushing, 2011).

Another recent example is the programme "Global SRS", co-financed by the European Commission. This programme aims at spreading the use of SRS software (designed to allow content delivery and evaluation through mobile devices) through the design of a specific training module for trainers, and the development of a pilot programme to assess its use. The results were very positive, obtaining a high level of participation and positive evaluation of the tool's advantages (Almeida \& Moldovan, 2014).

Although most of these initiatives take place in university education, we can also find some experiences in continuing teacher training, like the one conducted by the UK Teacher Development Agency (Whishart, 2009).

The professionals in charge of this training must meet some requirements (Sandoval, García, \& Ramírez, 2012): Ability to adapt to an environment with rapid and constant changes, knowledge on technologies and their production tools, and communicational and pedagogical skills.

\section{5.- RESEARCH ON MLEARNING: FROM EUROPE TO SPAIN}

The research lines in mobile learning can be classified in three categories, depending on the focus of the investigation: technology, pedagogy or educational theory (Petrova \& Li, 2009):

- Research focused on the technology: They study subjects related to the usability of the mobile devices or the network transmission.

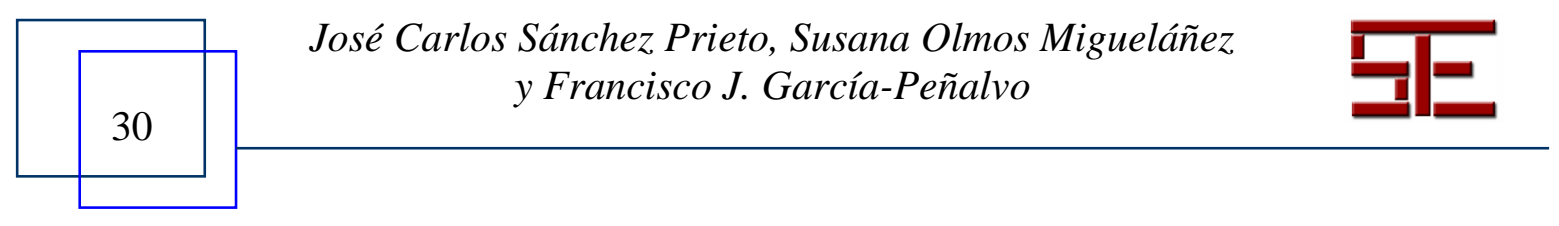




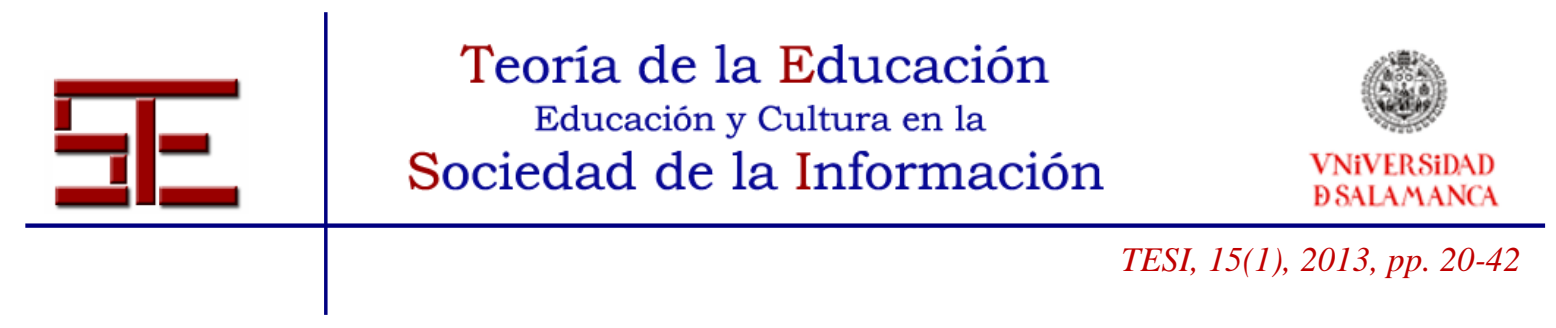

- Research focused on the educational theory: Related to the practical applications that these technologies may have within the educational theories.

- Research focused on the pedagogy: Dedicated to the design and evaluation of materials and their direct application. Their work has tangible products as a result.

In the analysis on the evolution of the amount of research inside each group performed by these authors, it was found that the majority of the investigations belong to the group focused on the technology, although the trend is the decrease of studies focused on this aspect and the growth of the number of investigations carried out by the other two groups, especially the third one.

$\mathrm{Wu}$ et al. (2012) confirm this in their study where, after analyzing 164 articles, they concluded that the majority (58\%) were centered in the evaluation of the effects of mobile learning. $32 \%$ were centered in the design of mobile systems for learning, $5 \%$ in investigating the affective domain and the remaining 5\% was centered in evaluating the learners' characteristics.

Traxler (2009) proposes a different classification of the investigations, focusing on the thematic:

-Mobile learning centered on the technology: A technological innovation is introduced in an educational context to measure its technological feasibility and educational possibilities.

- Miniaturized and portable eLearning: It involves implementing solutions already used in eLearning environments, after adapting them to mobile terminals.

- Classroom connected learning: To apply mobile technologies in the classroom to support collaborative learning. They may appear connected to other resources such as digital blackboards.

- Individualized, situated and personalized Mobile learning: Development and application of programs that help producing context aware educational experiences.

- Mobile training: The use of the mobile technology to improve the worker performance through the delivering of information and just-in-time support to attend their immediate needs.

- Mobile learning in remote and rural environments: Application of mLearning in distance learning experiences in places where conventional eLearning has no reach.

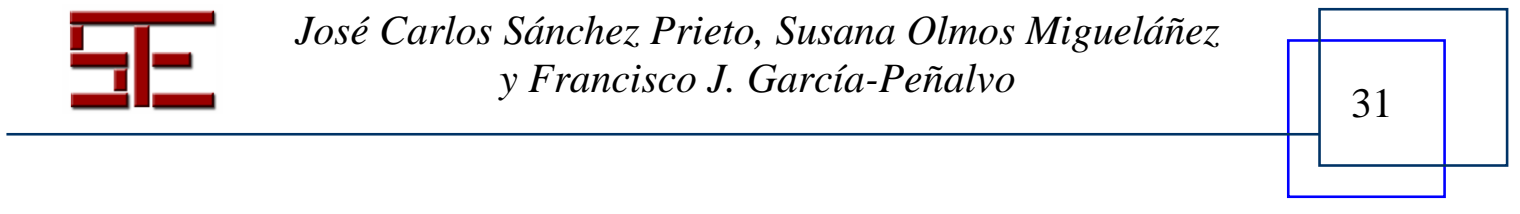




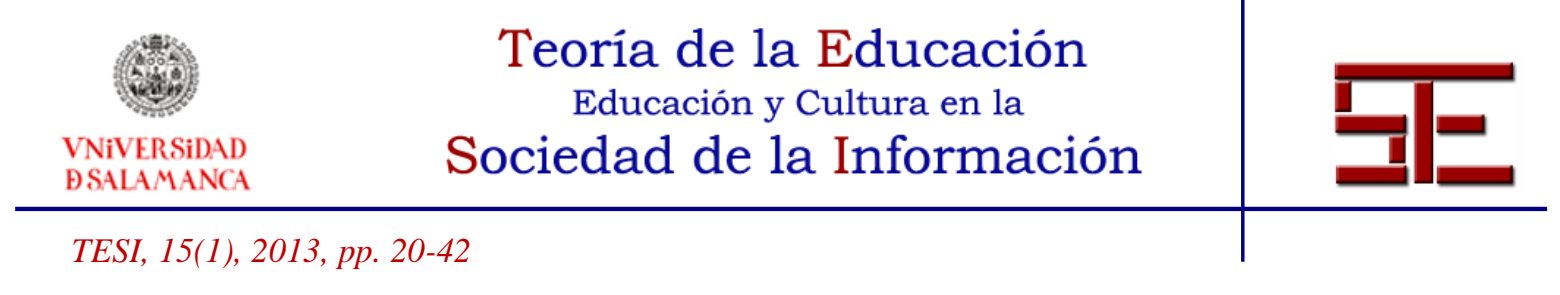

- The majority of subjects proposed by Traxler revolves around adult education and is strongly linked to distance education.

Currently we can find the following tendencies in mobile learning research:

-Located learning: The inclusion of geo-location capabilities in mobile devices allows the design of applications that relate to the location of the student (Oller, 2012).

- Serious Games: The screen resolution and graphics horsepower of tablets and smartphones allow the creation of interactive educational videogames (Masek, Murcia, \& Morrison, 2012).

- Augmented Reality (AR): Another application of tablets and smartphones that is currently being explored is their use in AR activities. AR superimposes virtual elements over the image of real elements through the combination of the screen and camera of the devices, thus permitting the interaction between these elements and the students. AR has been explored in diverse educational contexts ranging from Primary Education (Parhizkar et al., 2012) to University ( $\mathrm{H}$. Wu, Lee, Chang, \& Liang, 2013).

- Interactive Books: The use of tablets as a medium for interactive textbooks with multimedia content and interactive activities (Huang, Liang, Su, \& Chen, 2012b).

\section{1.- Mobile Learning in Europe}

In Europe, mLearning research began its development significantly with the explosion of the PDAs during the 90s. In those years, the studies were focused on the development of technologies (HandLeR), software architectures (MOBILearn) and service portals (mLearning).

With time, the number of investigations has increased. In Europe, the main characteristic of these investigations is that they are focused on the study of pedagogical implications. The subjects of research have been diversifying, including the following (Alonso de Castro, 2014; Kukulska-Hulme, Sharples, Milrad, Arnedillo-Sánchez, \& Vavoula, 2011; Oberer \& Erkollar, 2013; Wishart \& Triggs, 2010):

-Mobile learning in the schools: With projects that range from the application of known technologies (Learning2Go) to the creation of specific applications and programs (PI y Let's Go), or the use of mobile technologies in the context of an European network of schools.

- Mobile learning in higher education: They usually involve more participants than the rest of investigations We can find investigations focused on the use of SMS for the communication with the students, and podcast recordings

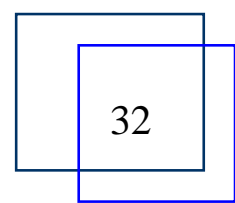

José Carlos Sánchez Prieto, Susana Olmos Migueláñez

y Francisco J. García-Peñalvo

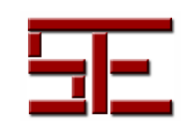




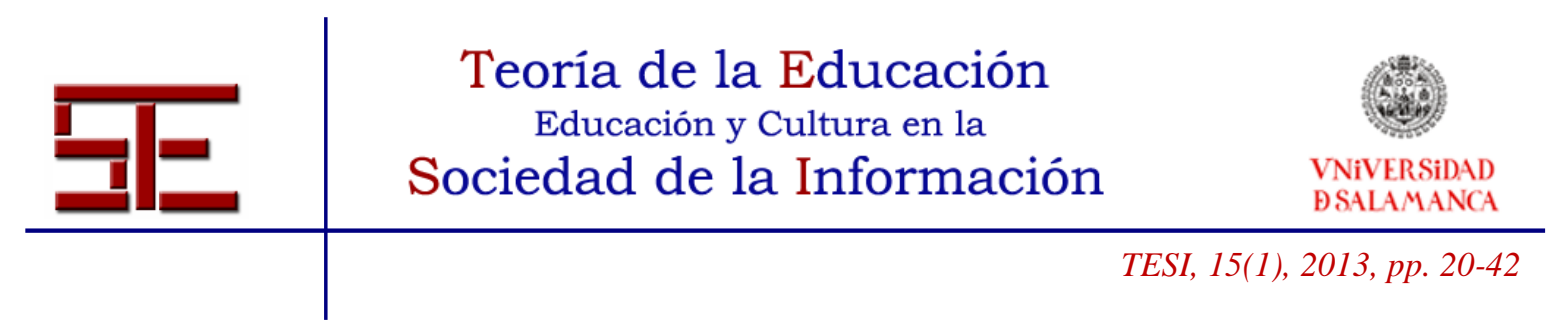

(StudyLink). There are also experiences with students doing internships (myPad project) or with the integration of mLearning modules in the regular classes.

- Mobile learning in museums and informal contexts: These are educational projects developed on informal education contexts. The majority of the projects use smartphones as communication devices and to receive and transmit data, like the projects Myartspace or Museumscouts, which explore the possibilities of using mobile devices to enhance the performance of school activities in museums.

- Mobile learning in work environments: Focused overall in medicine teaching (Knowmobile, Medimobile), in situ competence development (Personal Mobile Assistant) and teacher training.

-Mobile learning and lifelong learning: Within the UE's Lifelong Learning Programme, we can find interesting experiences which study the application of mobile technologies in different environments, such as: integration in risk groups (eFuture, ENSEMBLE), support to immigrants in work environments (Español a la carta) or the dissemination of good practices related to mlearning (Collage).

\section{2.- Mobile Learning in Spain}

Although mobile learning in Spain is still at an early stage of development, in the past few years there has been a growing amount of research ranging from the use of Augmented Reality programmes (Cadavieco, Goulão, \& Costales, 2012) to the development of language learning applications (Rodríguez-Arancón, Arús, \& Calle, 2013)

The learning environments are another field of interest, where we can find initiatives like the project MPLE (Mobile Personal Learning Environment), a project funded by the Board of Castile and Leon that aims to develop the concept of Personal Learning Environment in mobile contexts through " a service-based approach to the definition of mobile personal learning environments that facilitates communication with institutional learning platforms" (Conde González, García Peñalvo, Alier, \& Piguillem, 2013) and which has developed a pilot experience in the University of Salamanca that has yielded positive results.

Within formal education there are some pilot experiences being conducted, such as Proyecto DEDOS, developed by the CITA to study the use of tablets in the classroom (CITA, 2010) or the one conducted by Kucircove, Messer, Sheehy and Fernández Panadero (2014) to study the engagement capacity of tablets with pre-primary students.

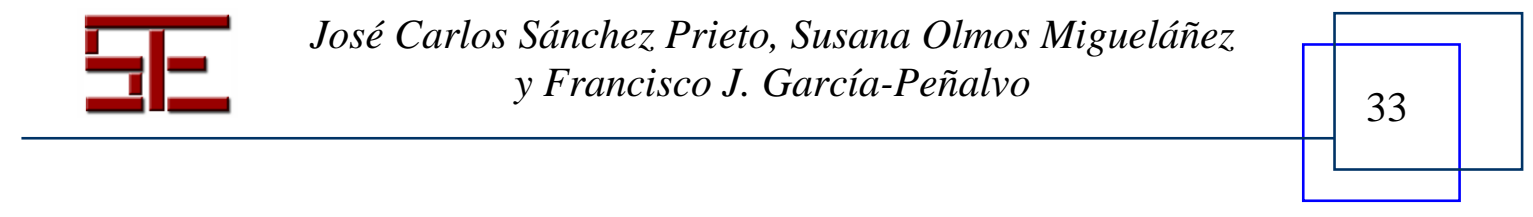




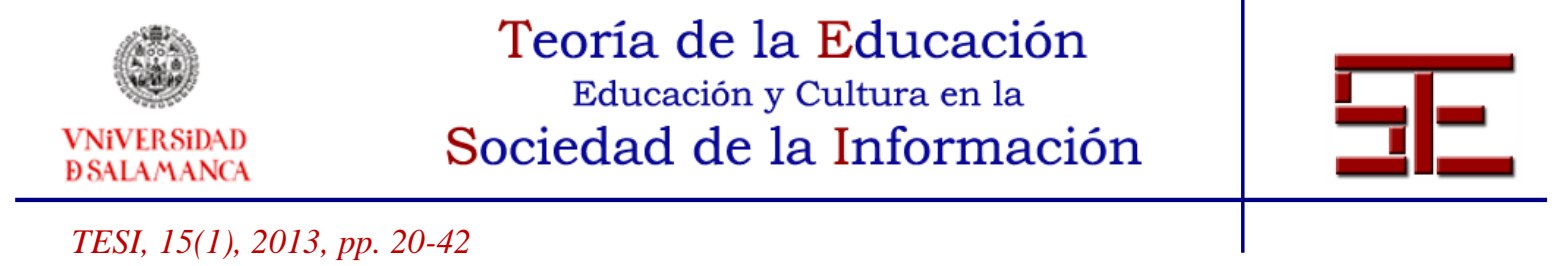

Fernández López, Rodríguez Fórtiz, Rodríguez Almendros and Martínez Segura (2013) developed a study about the possibilities of iPads in the support of students with special education needs through a platform of their own making called Picaa. The success of this experience has motivated the continuity of the platform and the project in partnership with other Special Education schools.

The most prominent case of mLearning in Spain is the one taking place in the EOI (Industrial Organization School). This programme has been successfully running since 2009, having trained more than 1000 students.

During the first edition, they decided on the use of smartphones, but currently these have been substituted by tablets, because they adjust better to the needs of mLearning. This Project has been developed using open software and cloud-based tools, such as Google Docs. Students and teachers have personalized accounts that provide them with access to the collaborative and communicational tools (chats, forums, wikis, etc.). Students also have at their disposal a personal blog service, within the EOI's blogosphere, through which they express their daily reflections and participate in the construction of shared knowledge.

The programme also has a virtual campus, based on the Moodle platform, where the courses are developed and which provides a meeting point for students and teachers. Lastly, social media is the fourth axis of this programme. The activities conducted in these spaces are aimed at raising awareness among the students about the importance of building a professional reputation through these tools (Tíscar, 2011).

\section{6.- CONCLUSIONS}

As we have established, mobile learning is a young phenomenon that is being developed at great speed on account of the growing interest that mobile technologies cause, and the penetration of smartphones and tablets.

This methodology comes to deepen the changes introduced by eLearning through the use of the devices' abilities to favor a more flexible, individualized, collaborative and multimedia teaching-learning process.

The proper development of this methodology requires pedagogy adjusted to the features of the new learning resources and situations, and a properly trained and motivated teaching body because, as we have seen in other occasions, the mere technological development does not result in a methodological improvement.

However, although the amount of research conducted from a didactic approach is raising, most research is still focused in the technological aspect. This may be caused by mobile learning being a relatively new methodology, which is only starting to attract the educational community's attention.

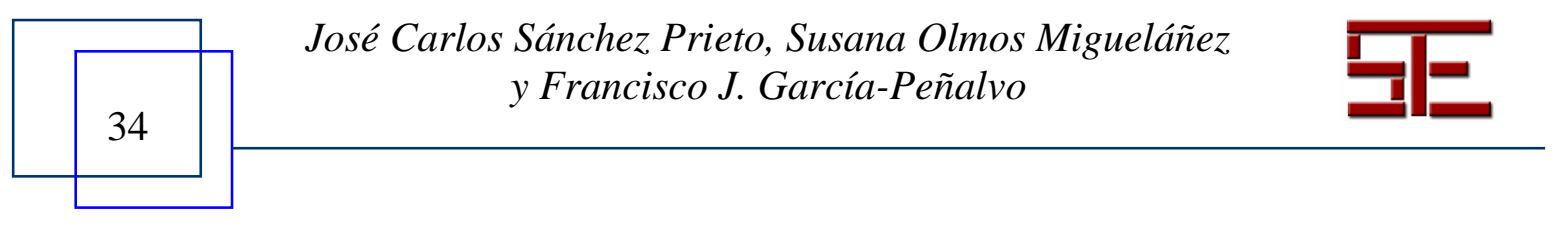




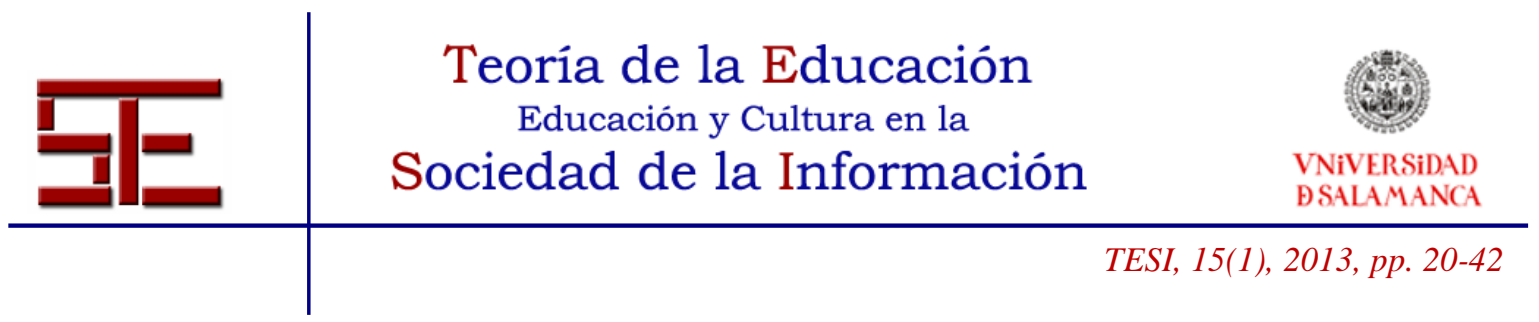

The UNESCO (2012) states that there is a stigma over mobile learning, a series of prejudices in the society, on a global level, that considers these terminals unsuitable for learning. Nevertheless, the different experiences have been demonstrating that this is not the case. A change of mentality is necessary, to make society realize this is a suitable alternative.

This change of mind must be based on the improvement in the quality of the mLearning programs, which depends on the appropriate development of the pedagogical approaches and the design of quality didactic activities.

\section{7.- BIBLIOGRAPHY}

Almeida, C. \& Moldovan, L. (2014). Mobile learning methodology for European trainers and VET systems quality improvement. Procedia Technology, 12 (0), 646653. DOI: http://dx.doi.org/10.1016/j.protcy.2013.12.544.

Alonso de Castro, Ma . G. (2014). Educational projects based mobile learning. Teoría De La Educación. Educación y Cultura en la Sociedad De La Información, In Press

Álvarez Rosado, N., Bravo Martín, S., García Peñalvo, F. J. \& Álvarez Rosado, S. (2013). Join the board. In Proceedings of the First International Conference on Technological Ecosystem for Enhancing Multiculturality, (pp.231-236) Salamanca, Spain. DOI: $10.1145 / 2536536.2536572$

Berlanga, A. J., García Peñalvo, F. J., \& Sloep, P. B. (2010). Towards eLearning 2.0 university. Interactive Learning Environments, 18 (3), 199-201. doi:10.1080/10494820.2010.500498.

Beschorner, B., \& Hutchison, A. (2013). iPads as a literacy teaching tool in early childhood. International Journal of Education in Mathematics, Science and Technology, 1 (1), 16-24.

Cadavieco, J. F., Goulão, M. d. F., \& Costales, A. F. (2012). Using augmented reality and m-learning to optimize students performance in higher education. Procedia Social and Behavioral Sciences, 46 (0), 2970-2977. doi: http://dx.doi.org/10.1016/j.sbspro.2012.05.599.

Camargo, M., Bary, R., Boly, V., Rees, M., \& Smith, R. (2011). Exploring the implications and impact of smartphones on learning dynamics: The role of selfdirected learning. Concurrent Enterprising (ICE), 2011 17th International Conference On, 1-7.

Carr, J. M. (2012). Does math achievement h'APP'en when iPads and game-based learning are incorporated into fifth-grade mathematics instruction? Journal of Information Technology Education, 11, 269-286.

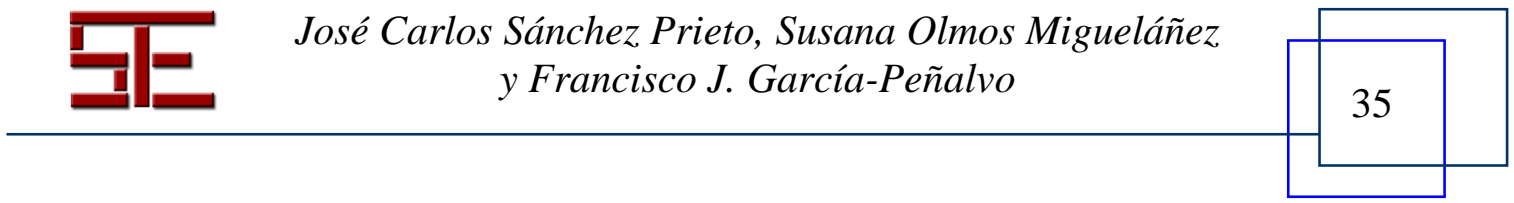




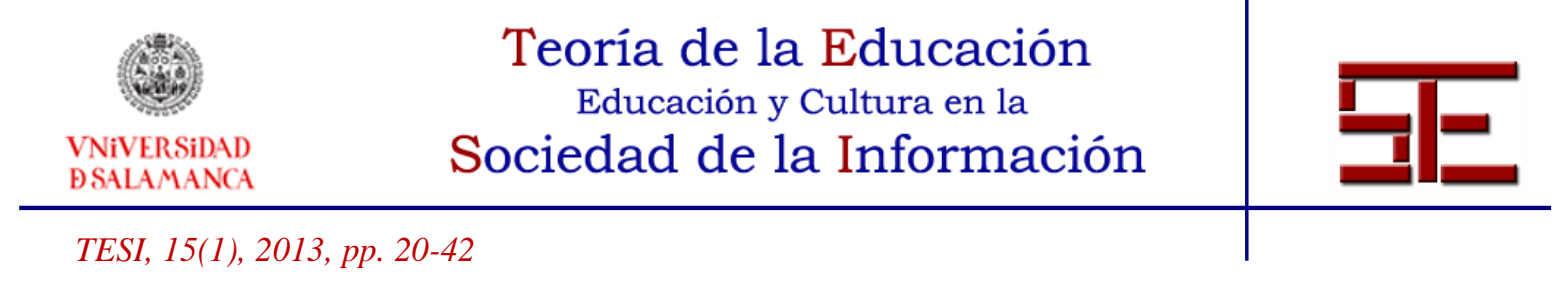

CITA (2010). DEDOS: Tabletas digitales en el aula. Retrieved on January 28, 2014, from

http://www.territorioebook.com/includes/descarga.php?id=../recursos/1298988498 _ProyectoDedos.pdf.

Cochrane, T. D. (2011). Beyond the yellow brick road: Mobile web 2.0 informing a new institutional E-learning strategy. Journal of Asynchronous Learning Networks, 15 (4), 60-68.

Cochrane, T. (2012). Secrets of mlearning failures: Confronting reality. Research in Learning Technology, 20 (-), 123-134. doi:10.3402/rlt.v20i0.19186.

Conde González, M. Á, García Peñalvo, F. J., Alier, M., \& Piguillem, J. (2013). The implementation, deployment and evaluation of a mobile personal learning environment. Journal of Universal Computer Science, 19(7), Retrieved on January 28,2014 , from http://www.jucs.org/jucs_19_7/the_implementation_deployment_and.

Conde, M. Á, Muñoz, C., \& García, F. J. (2008). mLearning, the first step in the learning process revolution. International Journal of Interactive Mobile Technologies (iJIM), 2 (4), 61-63.

Corbeil, J. R., \& Valdés-Corbeil, M. E. (2007). Are you ready for mobile learning? Educause Quarterly, 30 (2), 51-60.

Cushing, A. (2011). A case study of mobile learning in teacher training - MENTOR ME (mobile enhanced mentoring). MedienPädagogik, 19, 1-14.

Dündar, H., \& Akçayır, M. (2014). Implementing tablet PCs in schools: Students' attitudes and opinions. Computers in Human Behavior, 32 (0), 40-46. doi:http://dx.doi.org/10.1016/j.chb.2013.11.020

Elias, T. (2011). Universal instructional design principles for mobile learning. International Review of Research in Open and Distance Learning, 12 (2), 143-156.

Fernández Gómez, E., Baratech Ramírez, M., Fernández Izard, J. A., Lara Navarra, P., Rodríguez Vázquez, J. C., Sánchez Navarrete, L., . . Vázquez Vega, A. (2009). Ulearning. el futuro está aquí. Madrid: RA-MA Editorial.

Fernández-López, Á., Rodríguez-Fórtiz, M. J., Rodríguez-Almendros, M. L., \& Martínez-Segura, M. J. (2013). Mobile learning technology based on iOS devices to support students with special education needs. Computers \& Education, 61(0), 77-90. doi:http://dx.doi.org/10.1016/j.compedu.2012.09.014

Ferrer, F., Belvís, E., \& Pàmies, J. (2011). Tablet PCs, academic results and educational inequalities. Computers \& Education, 56(1), 280-288. doi: http://dx.doi.org/10.1016/j.compedu.2010.07.018.

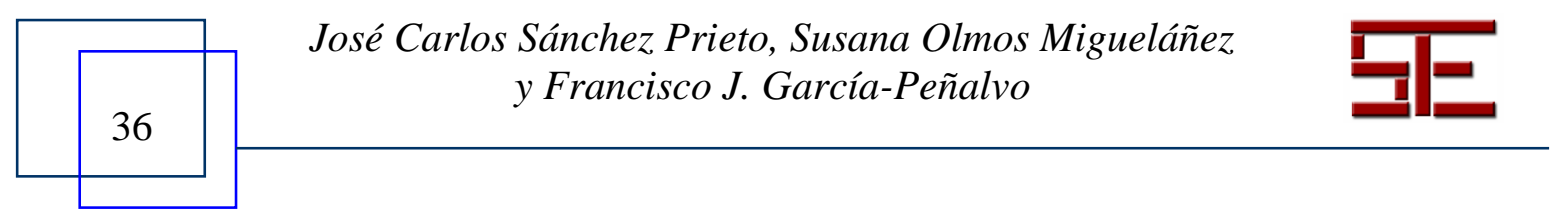




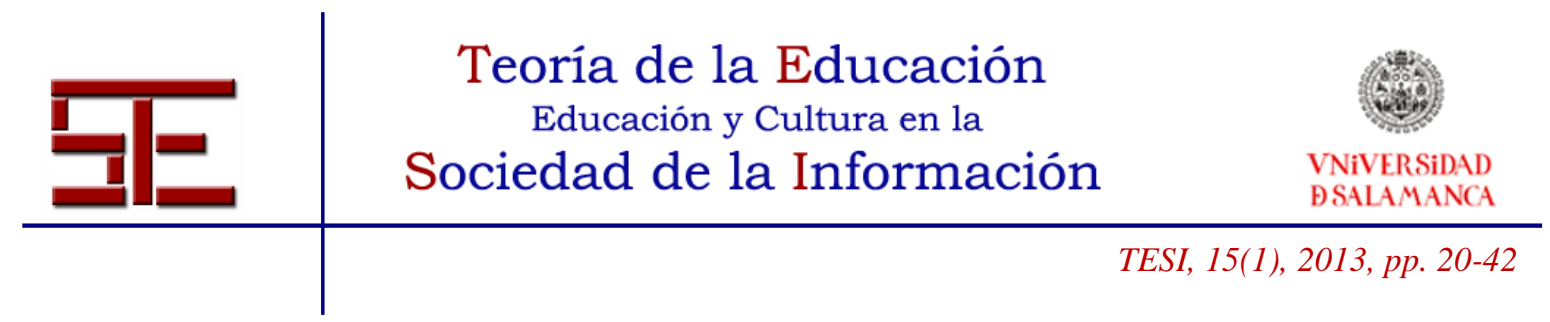

Franklin, T. (2011). MOBILE LEARNING : AT THE TIPPING POINT. Educational Technology, 10 (4), 261-275.

Fundación Telefónica (2013). La sociedad de la información en España 2013.

Retrieved on January 28, 2014, from

http://www.fundacion.telefonica.com/es/arte_cultura/publicaciones/sie/sie2013.htm

García-Peñalvo, F. J. (2005). Estado actual de los sistemas E-learning. Teoría De La Educación. Educación y Cultura en La Sociedad de la Información, 6 (2)

Germany, L. (2011). iTunes U: An opportunity for students. Campus-Wide Information Systems, 28 (3), 175-182. doi: 10.1108/10650741111145706

Gopalan, A., Karavanis, S., Payne, T., \& Sloman, M. (2011). Smartphone based Elearning. Proceedings of the 3rd International Conference on Computer Supported Education, Noordwijkerhout, Netherlands. 21-12.

Hesser, T. L., \& Schwartz, P. M. (2013). iPads in the science laboratory: Experience in designing and implementing a paperless chemistry laboratory course. Journal of STEM Education: Innovations \& Research, 14 (2), 5-9.

Huang, Y., Liang, T., Su, Y., \& Chen, N. (2012a). Empowering personalized learning with an interactive e-book learning system for elementary school students.

Educational Technology Research and Development, 60 (4), 703-722. doi:10.1007/s11423-012-9237-6.

- (2012b). Empowering personalized learning with an interactive e-book learning system for elementary school students. Educational Technology Research and Development, 60 (4), 703-722. doi: 10.1007/s11423-012-9237-6.

Humanante Ramos, P., \& García Peñalvo, F. J. (2013). Contribution of virtual classrooms to the personal learning environments (PLE) of the students of the career of informatics applied to education of national university of chimborazo. Proceedings of the First International Conference on Technological Ecosystem for Enhancing Multiculturality, (pp. 507-513) Salamanca, Spain. doi:10.1145/2536536.2536614

Hutchison, A., Beschorner, B., \& Schmidt-Crawford, D. (2012). Exploring the use of the iPad for literacy learning. The Reading Teacher, 66 (1), 15-23. doi:10.1002/TRTR.01090

Ifenthaler, D., \& Schweinbenz, V. (2013). The acceptance of tablet-PCs in classroom instruction: The teachers' perspectives. Computers in Human Behavior, 29 (3), 525-534. doi:http://dx.doi.org/10.1016/j.chb.2012.11.004

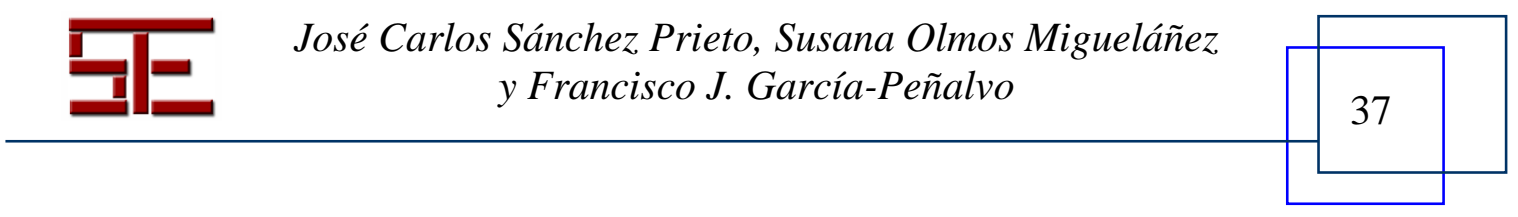




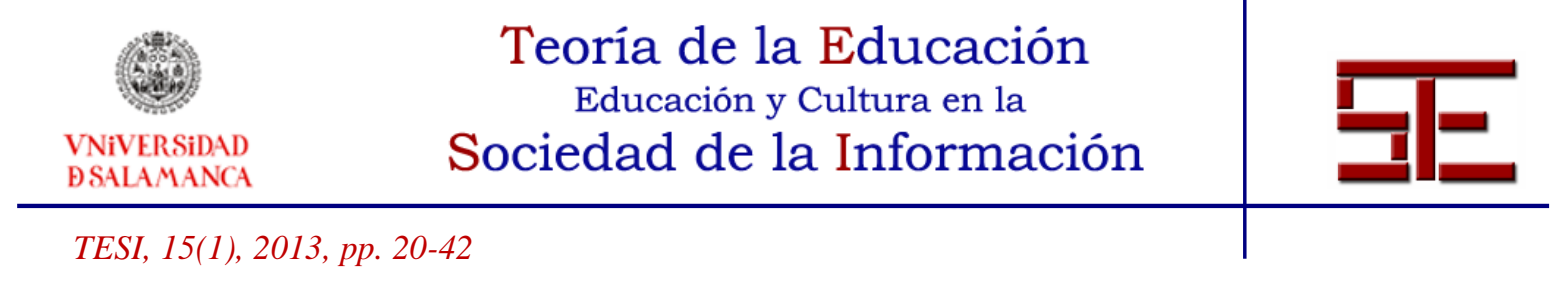

Jarvela, S., Naykki, P., Laru, J., \& Luokkanen, T. (2007). Structuring and regulating collaborative learning in higher education with wireless networks and mobile tools. Educational Technology \& Society, 10 (4), 71-79.

Jones, V., \& Jo, J. H. (2004). Ubiquitous learning environment: An adaptive teaching system using ubiquitous technology. In R. Atkinson, C. McBeath, D. Jonas-Dwyer $\&$ R. Phillips (Eds.), Beyond the comfort zone: Proceedings of the 21st ASCILITE (pp. 468-474).

Kadirire, J. (2009). Mobile learning demystified. In R. Guy (Ed.), The evolution of mobile teaching and learning (pp. 15-57). Santa Rosa, California: Informing Science Press.

Kamaruzaman, M. F., \& Zainol, I. H. (2012). Behavior response among secondary school students development towards mobile learning application. Humanities, Science and Engineering (CHUSER), 2012 IEEE Colloquium On, 589-592. doi: 10.1109/CHUSER.2012.6504381.

Korucu, A. T., \& Alkan, A. (2011). Differences between m-learning (mobile learning) and e-learning, basic terminology and usage of m-learning in education. Procedia Social and Behavioral Sciences, 15 (0), 1925-1930. doi:http://dx.doi.org/10.1016/j.sbspro.2011.04.029

Kucirkova, N., Messer, D., Sheehy, K., \& Fernández Panadero, C. (2014). Children's engagement with educational iPad apps: Insights from a Spanish classroom. Computers \& Education, 71 (0), 175-184. doi: http://dx.doi.org/10.1016/j.compedu.2013.10.003

Kukulska-Hulme, A., Sharples, M., Milrad, M., Arnedillo-Sánchez, I., \& Vavoula, G. (2011). The genesis and development of mobile learning in Europe. In D. Parsons (Ed.), Combining E-larning and m-learning: New applications of blended resources (pp. 151-177). IGI Global. doi: 10.4018/978-1-60960-481-3.ch010

Laouris, Y., \& Eteokleous, N. (2005). We need an educationally relevant definition of mobile learning. Proceedings of the 4 Th World Conference on mLearning. Cape Town, South Africa.

Lum, L. (2012). The move to mobile: Where is a campus's place in the mobile space? CURRENTS, v38 N4 p18-20, 22-25 Apr 2012, 38 (4), 18-20.

Mandula, K., Meday, S. R., Muralidharan, V., \& Parupalli, R. (2013). A student centric approach for mobile learning video content development and instruction design. Advanced Communication Technology (ICACT), 2013 15th International Conference On, 386-390.

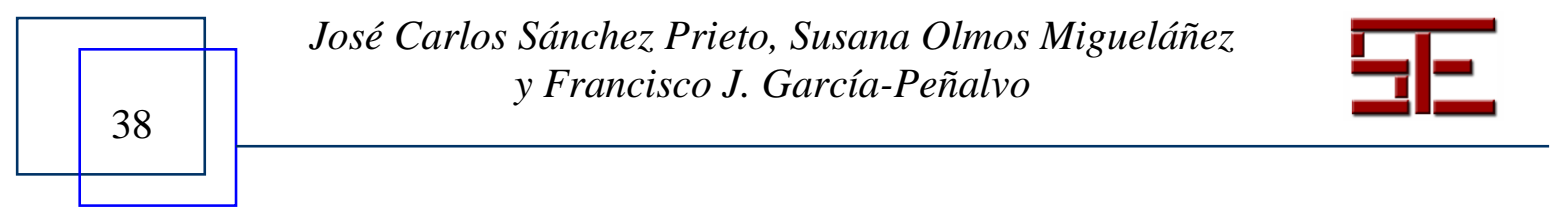




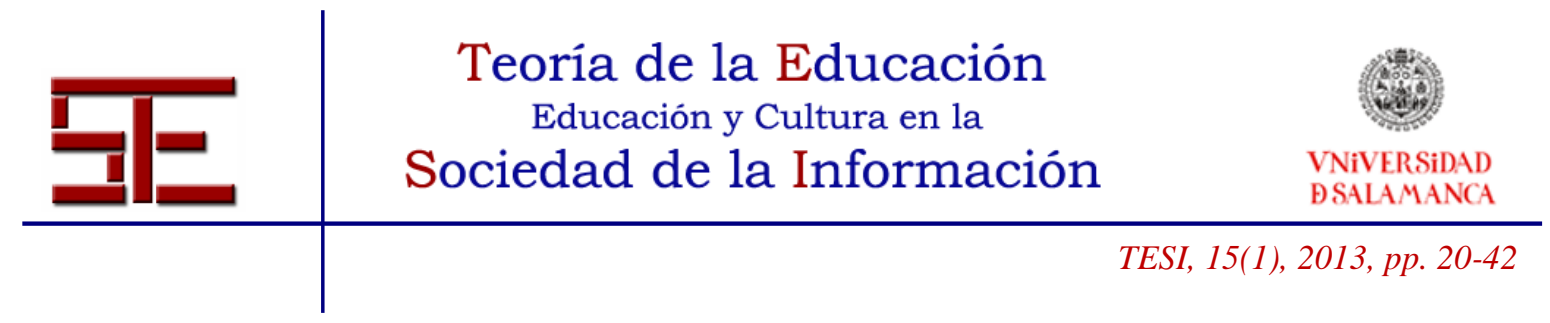

Marcos, L., Támez, R., \& Lozano, A. (2009). Aprendizaje móvil y desarrollo de habilidades en foros asincrónicos de comunicación. Revista Comunicar, 17(33), 93100. doi: http://dx.doi.org/10.3916/c33-2009-02-009.

Masek, M., Murcia, K., \& Morrison, J. (2012). Getting serious with iPads: The intersection of game design and teaching principals. Australian Educational Computing, 27 (2), 34-38.

Merchant, G. (2012). Mobile practices in everyday life: Popular digital technologies and schooling revisited. British Journal of Educational Technology, 43 (5), 770-782. doi:10.1111/j.1467-8535.2012.01352.x.

Moore, M. G. (2007). The theory of transactional distance. In M. G. Moore (Ed.), Handbook of distance education (pp. 89-105). Mahwah, N.J.: Lawrence Erlbaum Associates.

Murray, O., \& Olcese, N. (2011). Teaching and learning with iPads, ready or not? TechTrends, 55 (6), 42-48. doi:10.1007/s11528-011-0540-6.

O’Malley, C., Vavoula, G., Glew, J. P., Taylor, J., Sharples, M. \& Lefere, P. (2003). Guidelines for learning/teaching/tutoring in a mobile environment. Retrieved on January 28, 2014, from http://www.mobilearn.org/download/results/guidelines.pdf.

Oberer, B., \& Erkollar, A. (2013). Mobile learning in higher education: A marketing course design project in austria. Procedia - Social and Behavioral Sciences, 93 (0), 2125-2129. doi: http://dx.doi.org/10.1016/j.sbspro.2013.10.177.

Oller, R. (2012). The future of mobile learning. Retrieved 01/28, 2014, from http://www.educause.edu/library/resources/future-mobile-learning

Organista, J. \& Serrano, A. (2011). Implementación de una actividad educativa en modo colaborativo con apoyo de smarthphones: Una experiencia universitaria. EDUTEC, Revista Electrónica de Tecnología Educativa, (36). Retrieved on January 28, 2014, from http://edutec.rediris.es/revelec2/revelec36.

Orr, G. (2010). A review of literature in mobile learning: Affordances and constraints. 2010 6th IEEE International Conference on Wireless Mobile and Ubiquitous Technologies in Education, 0, 107-111. doi: 10.1109/WMUTE.2010.20.

Parhizkar, B., Gebril, Z. M., Obeidy, W. K., Ngan, M. N. A., Chowdhury, S. A., \& Lashkari, A. H. (2012). Android mobile augmented reality application based on different learning theories for primary school children. Multimedia Computing and Systems (ICMCS), 2012 International Conference On, 404-408. doi:

10.1109/ICMCS.2012.6320114.

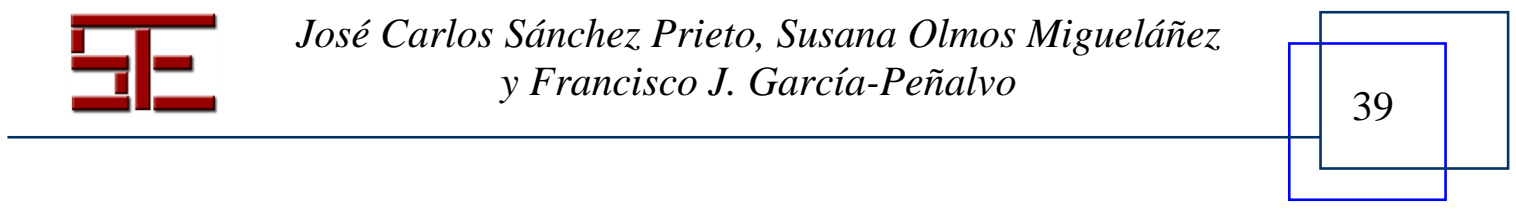




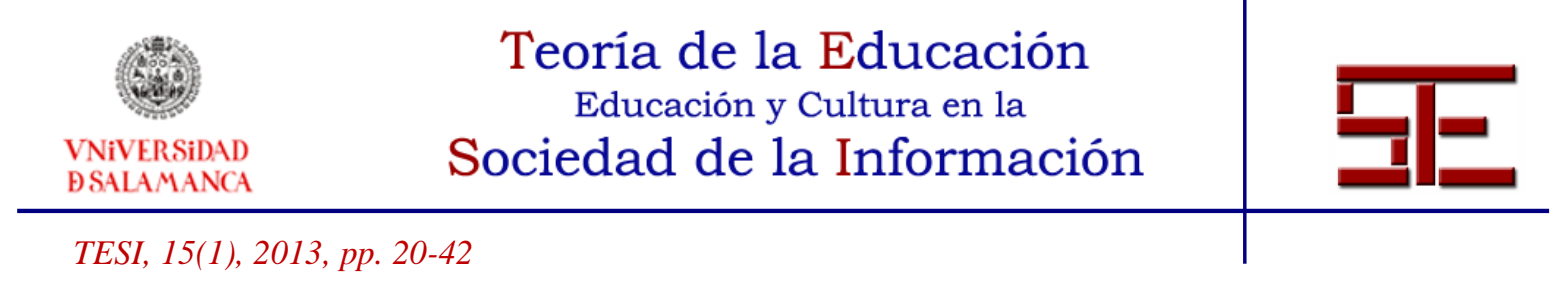

Park, Y. (2011). A pedagogical framework for mobile learning: Categorizing educational applications of mobile technologies into four types. The International Review of Research in Open and Distance Learning, 12 (2), 78-102.

Parnell, W., \& Bartlett, J. (2012). iDocument: How smartphones and tablets are changing documentation in preschool and primary classrooms. Young Children, 67 (3), 50-57.

Pegrum, M., Oakley, G., \& Faulkner, R. (2013). Schools going mobile: A study of the adoption of mobile handheld technologies in Western Australian independent schools. Australasian Journal of Educational Technology, 29 (1), 66-81.

Peters, K. (2007). M-learning: Positioning educators for a mobile, connected future. The International Review of Research in Open and Distance Learning, 8 (2)

Petit, J., \& Kukulska-Hulme, A. (2011). Mobile 2.0: Crossing the border into formal learning? In M. J. W. Lee, \& C. McLoughlin (Eds.), Web 2.0-based E-learning: Applying social informatics for tertiary teaching (pp. 192-208). Hershey: IGI Global. doi: 10.4018/978-1-60566-294-7.

Petrova, K., \& Li, C. (2009). Focus and setting in mobile learning research: A review of the literature. Comunications of the IBIMA, 10(26), 219-226.

Quinn, C. (2000). Mlearning: Mobile, wireless, in-your-pocket learning. Retrieved on January 28, 2014, from http://www.linezine.com/2.1/features/cqmmwiyp.htm.

Ramírez Montoya, M. S. (2009). Recursos tecnológicos para el aprendizaje móvil (mlearning) y su relación con los ambientes de educación a distancia: Implementaciones e investigaciones. Revista Iberoamericana de Educación a Distancia, 12(2), 57-82.

Rodrigo, R. L. (2011). Mobile teaching versus mobile learning. Retrieved on January 28, 2014, from http://www.educause.edu/ero/article/mobile-teaching-versusmobile-learning

Rodríguez-Arancón, P., Arús, J., \& Calle, C. (2013). The use of current mobile learning applications in EFL. Procedia - Social and Behavioral Sciences, 103(0), 11891196. doi:http://dx.doi.org/10.1016/j.sbspro.2013.10.446.

Rossing, J. P., Miller, W. M., Cecil, A. K., \& Stamper, S. E. (2012). iLearning: The future of higher education? student perceptions on learning with mobile tablets. Journal of Scholarship of Teaching and Learning, 12 (2), 1-26.

Sandoval, E. A., García, R., \& Ramírez, M. S. (2012). Competencias tecnológicas y de contenido necesarias para capacitar en la producción de recursos de aprendizaje móvil. EDUTEC, Revista Electrónica de Tecnología Educativa, (39), Retrieved on January 28, 2014, from

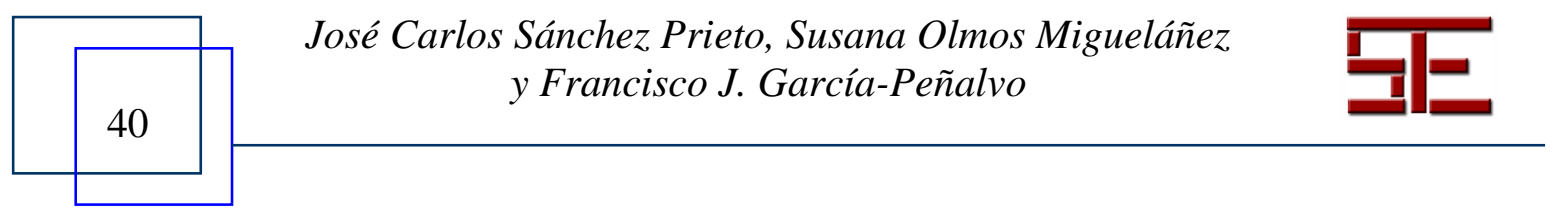




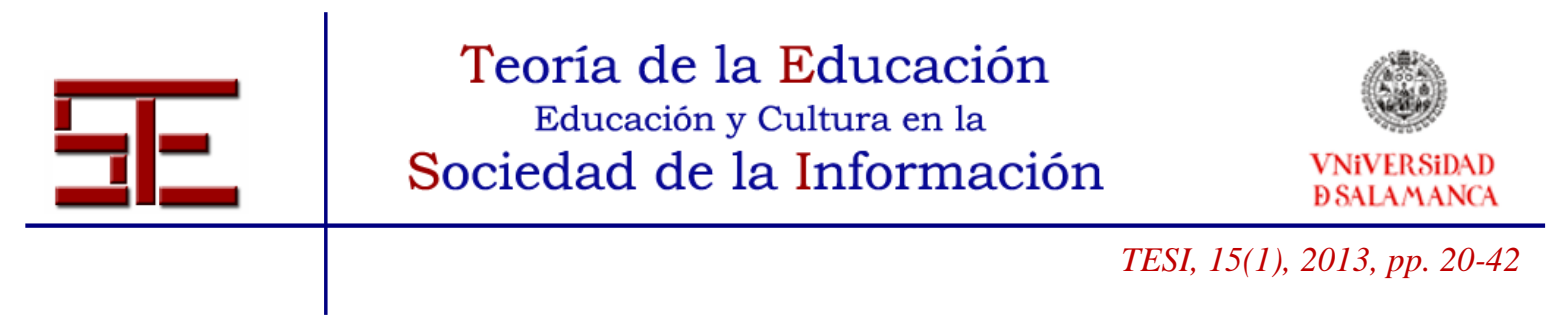

http://edutec.rediris.es/Revelec2/Revelec39/competencias_tecnologicas_contenido_ capacitacitar_produccion_recursos_aprendizaje_movil.html.

SCOPEO. (2011). M-learning en españa, portugal y américa latina. Retrieved on January 28, 2014, from http://scopeo.usal.es/sites/all/files/scopeom003.pdf

Sharples, M., Amedillo Sanchez, I., Milrad, M., \& Vavoula, G. (2009). Mobile learning: Small devices, big issues. In N. Balacheff, S. Ludvigsen, T. d. Jong \& S. Barnes (Eds.), Technology enhanced learning: Principles and products (pp. 233-249). Heidelberg: Springer.

Shin, D., Shin, Y., Choo, H., \& Beom, K. (2011). Smartphones as smart pedagogical tools: Implications for smartphones as u-learning devices. Computers in Human Behavior, 27(6), 2207-2214. doi:http://dx.doi.org/10.1016/j.chb.2011.06.017

Taylor, J. (2006). Evaluating mobile learning: What are appropriate methods for evaluating learning in mobile enviroments? In M. Sharples (Ed.), Big issues in mobile learning (pp. 25-27) University of Nottingham.

Terras, M. M. \& Ramsay, J. (2012). The five central psychological challenges facing effective mobile learning. British Journal of Educational Technology, 43 (5), 820832. doi: 10.1111/j.1467-8535.2012.01362.x.

Tíscar, L. (2011). Mobile learning EOI: Abriendo el aula. Retrieved on January 28, 2014, from http://www.eoi.es/blogs/mlearning/files/2011/06/mlearning_eoi_2011.pdf.

Traxler, J. (2009). Current state of mobile learning. In M. Ally (Ed.), Mobile learning: Transforming the delivery of education and training (pp. 9-25). Edmonton: AU Press.

UNESCO (2012). Working paper series on mobile learning. Retrieved on January 28, 2014, from http://www.unesco.org/new/en/unesco/themes/icts/m4ed/mobilelearning-resources/unescomobilelearning»series/.

Whishart, J. (2009). Use of mobile technology for teacher training. In M. Ally (Ed.), Mobile learning: Transforming the delivery of education and training (pp. 265248). Edmonton: AU Press.

Wishart, J., \& Triggs, P. (2010). MuseumScouts: Exploring how schools, museums and interactive technologies can work together to support learning. Computers \& Education, 54 (3), 669-678. doi:http://dx.doi.org/10.1016/j.compedu.2009.08.034

Wu, H., Lee, S. W., Chang, H., \& Liang, J. (2013). Current status, opportunities and challenges of augmented reality in education. Computers \& Education, 62 (0), 4149. doi:http://dx.doi.org/10.1016/j.compedu.2012.10.024

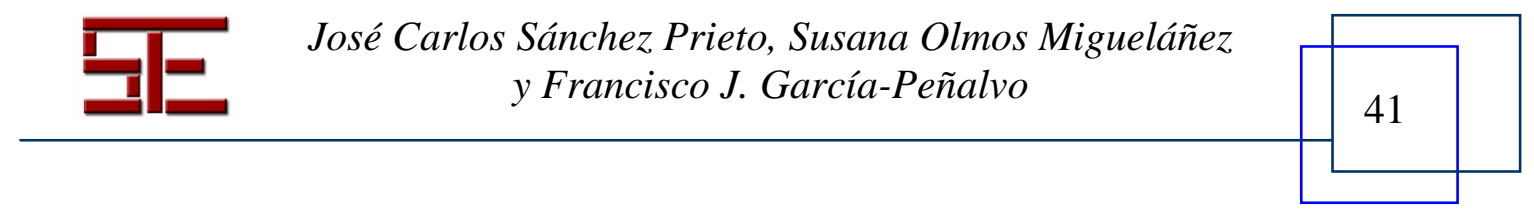




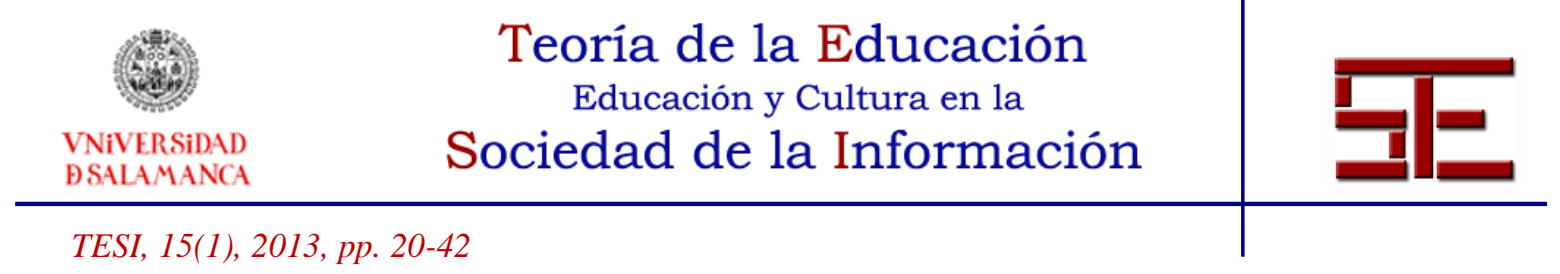

Wu, W., Jim Wu, Y., Chen, C., Kao, H., Lin, C., \& Huang, S. (2012). Review of trends from mobile learning studies: A meta-analysis. Computers \& Education, 59 (2), 817-827. doi:http://dx.doi.org/10.1016/j.compedu.2012.03.016.

Zhang, B., Looi, C., Seow, P., Chia, G., Wong, L., Chen, W., Norris, C. (2010). Deconstructing and reconstructing: Transforming primary science learning via a mobilized curriculum. Computers \& Education, 55 (4), 1504-1523.

doi:http://dx.doi.org/10.1016/j.compedu.2010.06.016

Para citar el presente artículo puede utilizar la siguiente referencia:

Sánchez Prieto, J. C., Olmos Migueláñez, S. y García-Peñalvo, F. J. (2014). Understanding mobile learning: devices, pedagogical implications and research lines. Revista Teoría de la Educación: Educación y Cultura en la Sociedad de la Información. 15(1), 20-42 [Fecha de consulta: dd/mm/aaaa].

http://campus.usal.es/ revistas_trabajo/index.php/revistatesi/article/view/11651/12066

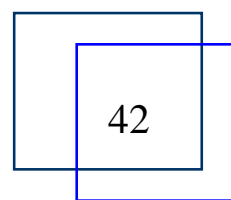

José Carlos Sánchez Prieto, Susana Olmos Migueláñez

y Francisco J. García-Peñalvo 